\title{
A taxonomy of measures for smart cities
}

\author{
Judy Backhouse \\ United Nations University (UNU-EGOV) \\ Portugal \\ backhouse@unu.edu
}

\begin{abstract}
As the idea of a smart city has developed over the past few decades and become commonplace, so the urge to decide which cities are smarter or smartest, and the need to measure progress of cities towards increasing smartness have emerged. Measuring the functioning of cities is complex given that they consist of many intersecting systems. Many different measures have been proposed, tested, and in some cases, implemented. This array of measures results in confusion for researchers, policy makers and city management. This review of the academic and practitioner literature, as well as web sites, identified and examined fifty-three different measures for cities. The characteristics of these measures were analysed based on information available from desktop research. Four types and twelve sub-types of smart city measures were identified. From this analysis, a taxonomy of smart city measures is presented. The potential uses of each subtype within the taxonomy are discussed.
\end{abstract}

\section{CCS CONCEPTS}

- Applied computing $\rightarrow$ Computers in other domains $\rightarrow$ Computing in government $\rightarrow$ E-government

\section{KEYWORDS}

Smart city measure; smart city indicator; smart city index; smart city model; maturity model; indicator standard; taxonomy

\section{ACM Reference format:}

Judy Backhouse. 2020. A taxonomy of measures for smart cities. In Proceedings of the $13^{\text {th }}$ International Conference on Theory and Practice of Electronic Governance (ICEGOV 2020), 23-25 September 2020, Athens, Greece. 11 pages. https://doi.org/10.1145/3428502.3428593
Permission to make digital or hard copies of all or part of this work for personal or classroom use is granted without fee provided that copies are not made or distributed for profit or commercial advantage and that copies bear this notice and the full citation on the first page. Copyrights for components of this work owned by others than the author(s) must be honored. Abstracting with credit is permitted. To copy otherwise, or republish, to post on servers or to redistribute to lists, requires prior specific permission and/or a fee. Request permissions from Permissions@acm.org.

ICEGOV'20, September 23-25, 2020, Athens, Greece

(c) 2020 Copyright is held by the owner/author(s). Publication rights licensed to ACM. ACM ISBN 978-1-4503-7674-7/20/09...\$15.00

https://doi.org/10.1145/3428502.3428593

\section{INTRODUCTION}

Cities and other human settlements are central to the experience of people on a daily basis, but also over longer periods. Many of the Sustainable Development Goals (SDGs) work towards improving this experience for as many people as possible. In particular, SDG 11, Sustainable Cites and Communities, focuses on how we can improve cities and human settlements.

Information and communication technologies (ICTs) provide tools for addressing some of these priorities. ICTs make it possible to collect and intelligently process data to better understand urban environments. Modelling tools facilitate experimentation and design of better urban systems. Communication tools make it possible to harness the experience and creativity of a wider pool of people to address urban challenges. This kind of use of ICTs in cities led to the idea of a smart city [1]. More recent concern for economic and environmental sustainability has shifted the focus to how to create smart cities that are also sustainable [2,3].

In order to assess whether cities are improving, it is necessary to measure and report on progress. However, measuring the progress of cities is complex and there is a large number of different measures in use. Cities need to decide what aspects of a city to measure, what indicators to use for those measures, and how to use the results to reach their own specific goals.

Defining city indicators takes skill and while cities can draw on standard indicator sets, selecting from among them is complex [4]. Interpreting indicators requires expertise as does setting up appropriate data collection and management procedures. Turning indicators into a holistic picture of city functioning is also complex. Two approaches to this are evaluation models [5,6,7] and composite indices $[8,9]$. Cities need to select high-quality approaches that are appropriate for their circumstances, but often lack information about alternatives or an understanding of the application of different measures.

At the same time there are indices that are used to rank cities in terms such as their "liveability" [10], quality of life [11], or their ability to support innovation [12], among other criteria. Such 
indices are presented on web sites and the annual results can attract considerable press coverage. It is not always clear what these different rankings mean and, for cities, whether they are worth participating in or how to respond to the consequences of being a participant.

Cities lack information and guidance as to what measures exist and how to evaluate and apply them. This makes it difficult for cities to accurately measure their progress. It also means that cities do not use comparable measures, making it difficult to get a national, regional or global picture of the state of cities.

As a first step towards addressing these concerns, this paper used a review of academic literature as well as online practitioner resources to collect a set of fifty-three measures for smart, sustainable cities and develop a taxonomy to describe these measures. The different measures were analysed in terms of their purpose and application. This taxonomy will assist researchers in understanding the range and nature of measures available. The analysis of the uses of these measures may be helpful in developing guides for practitioners.

\section{BACKGROUND AND RESEARCH QUESTIONS}

\subsection{Research into city measures}

The concept of a smart city is contested and open to many different interpretations [13]. For some, a smart city is about the application of information and communication technology (ICT) to the functioning of a city; often also called a digital or wired city $[1,13]$. For others, the smart city is about economic growth or "business-led urban development" [13]. A third discourse is about the smart inhabitants of the city [14] and their preferences for a space that is convenient and pleasant to live in [15]. More recently, there is a discourse about the city as sustainable [16,17] which has become intertwined with the idea of a smart city $[2,3]$.

A practical approach to these different discourses was taken by ITU-T who examined different definitions of a smart city and analysed those definitions to arrive at their own, comprehensive and inclusive definition of a smart, sustainable city as: "an innovative city that uses information and communication technologies (ICTs) and other means to improve quality of life, efficiency of urban operation and services, and competitiveness, while ensuring that it meets the needs of present and future generations with respect to economic, social and environmental aspects" [18].

While some of the smart city discourse focuses on whether a city is or is not smart $[19,20]$, others are concerned with how cities can become smarter, and more sustainable over time [6]. Whether looking to achieve the status of "smart", or simply to become smarter, cities need measures for smartness.

One way to measure cities is to measure their individual components or domains. Many models have been proposed for these. Examples include (1) smart economy, smart mobility, smart environment, smart people, smart living and smart governance [14,21], (2) ICT and information, governance, quality of life, infrastructure and services, people and society, environment and sustainability, economy and mobility [22] and (3) the components of a city that can be deduced from the SDG11 targets: housing and basic services, transport, urban planning, the protection of natural and cultural heritage, disaster management, environmental impact, public spaces, the links between urban and rural centres, policies to address climate change and support for least developed countries [23]. A somewhat simpler approach, has been to categorise the elements of the city in three broad areas: actions and initiatives with economic outcomes, those focused on the occupants of a city or community and those that focus on the environment $[4,24]$.

The idea that a city is the sum of its parts can be seen in many of the measures proposed for cities. Many of them measure the performance of a set of city components and use this data, often with a simple average or weighted average, to ascertain the overall functioning of a city $[25,26]$. However, a city is comprised of many different systems and the success of the city as a whole, depends not only on how well each part functions, but also on the interconnections between these systems. Some attempts at measuring cities focus more on understanding the relationships between different elements of the city rather than a single overall measure [27,28].

Measures of city performance often rely on indicators that have been classified as first- second- and third-order [29], where first-order outcomes refer to changes to the local government organisation, second-order outcomes are changes in the relationships between government and other urban actors and third-order outcomes are "improvements to the city". Others classify indicators in terms of input, process, output, outcome and impact [4]. Output, outcome and impact measures are preferred, and tend to use economic or social metrics [22,30,31] or in some cases, environmental [32]. However, input and process measures are important for cities that are in the early stages of making improvements when other measures may not yet be available or observable [4].

Many of the smart city measures focus on measuring capital cities (as representative of a country) or cities that are important centres of commerce or industry [33,34], but some researchers have developed measures that are useful for cities of different sizes and different stages of development [35, 36].

The data that is used for measuring smart cities has also come under scrutiny. Often the data used to measure cities is historical [37], collected by national or international bodies and some is collected by cities themselves [38]. Data may be missing or of poor quality [39] and need to be substituted by national data. An eloquent case has been made for the use of real-time data to measure smart cities [40], in effect making the measurement as smart as the smart city.

There are papers in the literature that argue for the value of specific techniques in measurement. For example, arguing for the value of using principal component analysis in the construction of indices as a tool for reducing the number of dimensions (or variables) that need to be measured while retaining a substantial amount of information [4].

Finally, the literature reflects many different reasons or purposes to measure cities. Some researchers are looking to understand the relationship between city characteristics and 
performance, such as the factors that impact wealth, in order to better define a smart city [37]. Others aim to identify characteristics and adverse conditions in cities that are most important for addressing their sustainable urban transformation $[5,6,7]$. Many measures aim at ranking cities according to defined criteria [10,41], such as their "attractive power" to creative individuals and business enterprises [34]. Some measures have more prosaic goals, such as to enable cities to access funding [42].

\subsection{Research questions}

The measurement of city performance is complex and multifaceted. Firstly, cities consist of many inter-related systems, each with their own goals and objectives [43], that impact each other. Second, cities answer to many different internal and external stakeholders [44] who may have conflicting ideas on what constitutes success for a city. Third, the selection of measures (and, indeed the decision to measure at all) is a socially defined act that is influenced by current discourses, prevailing beliefs and available information and the various centres of power that influence them.

This research aims to aid the process by cataloguing and characterising the different kinds of city measures currently in use. We are also interested in which measures might be most appropriate for what ends. Thus, the research questions that this paper seeks to answer are:

1) What measures of smart cities have been proposed and / or are being used?

2) What types of measures can be identified and what are their characteristics?

3) For what purposes are these measures intended or suited?

\section{RESEARCH METHODS}

This study is descriptive and based on desktop research carried out during 2019.

A review carried out by the United Nations University in 2016 [21] identified fifteen measures of smart cities that included indicator standards, indices and models. This list was expanded using searches of the academic literature, following references in identified papers to other measures, and through web searches as described below.

A search for smart city indices was conducted in May 2019, using the Web of Science, to identify journal or conference papers including the terms "smart city" and "index". This search returned 100 papers from which 16 were identified that reported on the construction or evaluation of unique indices for smart cities. In selecting these papers, duplicates (which reported on the same index) were eliminated, as were papers that constructed indices for only one aspect of a smart city (such as transport, happiness or the efficiency of construction), as well as papers for which the full text could not be obtained. The detailed process for this search is reported in [45].

The Google and Duck Duck Go search engines were used with the search strings "smart city index" and "smart city model" and the first two pages of results were examined for other city measures that met the same criteria.

While these initial searches focused on measures for smart cities, it became clear that, in the absence of an agreed definition of a smart city, and with the growing, overlap of research into smart and sustainable cities, it would be necessary to interpret a smart city generously, including measures for variants such as intelligent cities, creative cities, livable cities and sustainable cities. Subsequently, the search was expanded by following references and further web searches as described below.

Where articles made reference to other city measures, the references were followed up. Where they were established to be measures of the city's overall smartness or sustainability (and not only one aspect), they were added to the list. In some cases, there was limited information about the measure referred to and, in these cases, further information was sought using internet searches and searches of the academic and practitioner literature. In each case the criteria were to include measures that (1) considered the city as a whole and not just one aspect and (2) could be generously considered to measure a smart or sustainable city, allowing for the different discourses and understandings that have been imposed on these concepts.

For all of the measures identified in this process information was captured including the name of the measure, who originated it, the sources of information (references), the purpose, the target cities, the geographical region, whether the measure had been applied repeatedly, how many cities had been evaluated, the city dimensions that the measure evaluates, the number of underlying indicators (where appropriate), the data used and the rigour of the measurement process.

Analysis of the measures to arrive at a taxonomy proceeded in stages:

1) Collecting descriptive information about each measure and eliminating those that did not meet the criteria.

2) Analysing the types of measures and dividing the measures into types.

3) Analysing the nature and purpose of the measures and relating these to characteristics such as origin and type.

4) Analysing the measures within types to identify major sub-types for each type.

5) Refining the taxonomy by reviewing the different subtypes and particularly exceptional cases.

\section{SMART CITY MEASURES}

In total, fifty-three measures of smart cities were identified. The measures could be classified into four groups: indicator standards, models, indices and other measures. Indicator standards are sets of indicators designed to measure aspects of city performance. Models are maps of city constructs and how they are related, with some means of assessing the functioning of each construct or measuring the relationships between constructs. Composite indices assign a single measure to a city based on indicators that measure a number of different city dimensions. Indices are sometimes, but not always, based on an explicit model of the city dimensions and some have been validated to prove that they 
measure what they claim to measure, but the validation is often lacking. Finally, there were some measures which did not fall into the first three categories. Among the measures identified were 10 indicator standards, 9 models, 25 composite indices, and 9 other measures.

\subsection{Indicator standards}

Indicator standards are sets of indicators identified as suitable for measuring different aspects of a city. They are defined by standards bodies at international, regional or national level. Our searches identified ten indicator standards for cities.

Table 1: Indicator standards for cities

\begin{tabular}{|c|c|c|c|}
\hline NO. & NAME & ORIGIN & REF \\
\hline S1 & CITYkeys - Smart City KPIs & Research group & {$[46]$} \\
\hline S2 & $\begin{array}{c}\text { ETSI TS 103 463 KPIs for sustainable } \\
\text { digital multiservice cities }\end{array}$ & Regional body & {$[47]$} \\
\hline S3 & $\begin{array}{c}\text { ISO Sustainable Development of } \\
\text { Communities - Indicators for City } \\
\text { Services and Quality of Life 37120:2018 }\end{array}$ & $\begin{array}{c}\text { International } \\
\text { body }\end{array}$ & {$[48]$} \\
\hline S4 & $\begin{array}{c}\text { ISO Sustainable cities and communities } \\
\text { Indicators for Smart Cities 37122:2019 }\end{array}$ & $\begin{array}{c}\text { International } \\
\text { body }\end{array}$ & {$[49]$} \\
\hline S5 & $\begin{array}{c}\text { ISO Sustainable cities and communities } \\
\text { Indicators for Resilient Cities 37123 } \\
\text { (under development) }\end{array}$ & $\begin{array}{c}\text { International } \\
\text { body }\end{array}$ & {$[50]$} \\
\hline S6 & $\begin{array}{c}\text { ITU-T Y.4901/L.1601 KPIs related to the } \\
\text { use of ICT in SSCs }\end{array}$ & $\begin{array}{c}\text { International } \\
\text { body }\end{array}$ & {$[51]$} \\
\hline S7 & $\begin{array}{c}\text { ITU-T Y.4902/L.1602 KPIs related to the } \\
\text { sustainability impacts of ICT in SSCs }\end{array}$ & $\begin{array}{c}\text { International } \\
\text { body }\end{array}$ & {$[52]$} \\
\hline S8 & $\begin{array}{c}\text { ITU-T Y.4903/L.1603 KPIs for SSCs to } \\
\text { assess achievement of SDGs }\end{array}$ & $\begin{array}{c}\text { International } \\
\text { body }\end{array}$ & {$[53]$} \\
\hline S9 & $\begin{array}{c}\text { ITU-T "Key Performance Indicators in } \\
\text { Smart Sustainable Cities" }\end{array}$ & $\begin{array}{c}\text { International } \\
\text { body }\end{array}$ & {$[54]$} \\
\hline S10 & $\begin{array}{c}\text { SDG monitoring framework (indicators } \\
\text { for SDG11) (Inter-Agency and Expert } \\
\text { Group on SDG Indicators) }\end{array}$ & $\begin{array}{c}\text { International } \\
\text { bodies }\end{array}$ & {$[55]$} \\
\hline
\end{tabular}

Of the ten indicator standards, one was defined by a regional research group (S2), one by a regional body (S1). These regional organisations were both based in Europe and were defining standards to be applied to cities in Europe.

Three standards (S3, S4, S5) were defined by the International Organization for Standardization (ISO), four (S6, S7, S8, S9) by the International Telecommunications Union (ITU-T) and one (S10) by a group working across international agencies. Those defined by international bodies were intended to be applicable to cities globally.

Huovila et al. [4] examined the characteristics of smart city indicator sets and classified them in terms of their balance between indicators for smartness (further categorized as hard or soft) or sustainability (further categorized by people, planet or prosperity) and the types of indicators (input, process, output, outcome and impact) that they include. Their work provides an excellent assessment of the relevance of these indicator sets for specific applications.
Analysing the purposes expressed by the originators of indicator standards shows that most strive to help cities to achieve goals that are assumed for the cities. These include "wide-scale deployment of smart city solutions" (S1), "performance of city services and quality of life" (S2), "social, economic and environmental sustainability outcomes" (S3), "resilience” (S3) or improving perceptions of smartness (S6, S7, S8). Two of the sets (S9, S10) expect the measures to help cities to meet SDGs.

Three of the indicator standards state that their purpose is to have an ultimate impact on society. These include "to create impact on major societal challenges around the growth and densification of cities" (S1), to "steer" the performance of "city services and quality of life" (S2) and to "dramatically improve" the "social, economic and environmental sustainability outcomes" of cities (S3). Only two of the indicator standards aim to help to achieve goals that the cities define for themselves (S3, S5).

\subsection{Smart city models}

Models define a set of smart city constructs and how they are related. Models help to understand the complexity of cites by breaking the functioning of the city into multiple parts so that the functioning of each can be assessed.

The models identified in this process had more diverse origins than the other measures. Two (M6, M8) originated from a private company, one (M7) from a private consultant, three (M1, M2, M3) from academic research, one (M9) from an international body and one (M5) from a government-led partnership. Three of the models were developed for specific regions: European middle-sized cities (M3), Scottish cites (M4), Chinese cities (M2), and Chinese and European cities (M5). Three models (M6, M8, M9) were intended to apply to all cities, globally, while two (M1, M7) were not explicit about which cities they were intended for.

Table 2: Models for cities

\begin{tabular}{|c|c|c|c|}
\hline NO. & NAME & TYPE & REF \\
\hline M1 & $\begin{array}{c}\text { Model of smart city performance } \\
\text { (augmented triple helix and clustering) }\end{array}$ & Clustering & {$[7]$} \\
\hline M2 & $\begin{array}{c}\text { Modelling city development patterns in } \\
\text { China }\end{array}$ & Clustering & {$[6]$} \\
\hline M3 & $\begin{array}{c}\text { REMOURBAN (REgeneration MOdel } \\
\text { for accelerating the smart URBAN } \\
\text { transformation) }\end{array}$ & Clustering & {$[5]$} \\
\hline M4 & $\begin{array}{c}\text { Smart Cities Maturity Model and Self- } \\
\text { Assessment Tool (Scottish Cities }\end{array}$ & Maturity model & {$[56]$} \\
\hline M5 & $\begin{array}{c}\text { Smart City Assessment Framework (DG } \\
\text { CNET, EU Commission \& CATR) }\end{array}$ & Maturity model & {$[57]$} \\
\hline M6 & Smarter City Maturity Model (IBM) & Maturity model & {$[58]$} \\
\hline M7 & Boyd Cohen Smart City Wheel & Descriptive & {$[59]$} \\
\hline M8 & Municipal Reference Model (IBM) & Descriptive & {$[60]$} \\
\hline M9 & Policy Evaluation Model (UN-Habitat) & Descriptive & {$[61]$} \\
\hline
\end{tabular}

The models are of three different types: descriptive models, maturity models and clustering models. 
The descriptive models (M7, M8, M9) are the simplest. They define city functioning in terms of a number of dimensions and then define measures for each of these dimensions. In all three cases there was little detail about the sub-dimensions and the ways in which they were measured. The chief benefit of such models is that they enumerate the elements of the city to be measured ensuring that all of the selected dimensions are considered. The extent to which such measures are holistic depends, however, on the selection of dimensions in the model. These models differ from simple composite indices in that they do not attempt to arrive at a single measure for the city and tend to report measures for each dimension.

Three of these models (M4, M5, M6) follow the tradition of maturity models [62,63] originally used to evaluate the maturity of organisations based on their processes. Maturity models propose a set of levels through which an entity develops sequentially with each level characterised by defined achievements. These models can be used to measure maturity by comparing current characteristics with detailed descriptions of performance at each level.

Maturity models are useful because they do not require specialist skills to use, but they have been criticised for suggesting a single, linear development path (from infancy to maturity) without the possibility of variety $[64,65]$. To be effective they need detailed level descriptors with information about how the levels are to be assessed. Pöppelbuß and Röglinger [65] identified three levels of design principles for a useful maturity model, but none of the three models examined conform to even the first level, suggesting that these maturity models are of poor quality.

The first three models (M1, M2, M3) all make use of clustering techniques to group cities, although their approaches differ. Lombardi et al. [7] (M1) analyse the relationships between "smart city components" and the extended triple helix to identify cities as one of Entrepreneurial, Pioneer, Liveable and Connected, based on the emphasis given to each of universities, government, industry and civil society in the policy vision. Li et al. [6] (M2) analysed Chinese cities and identified six groups of cities with distinct patterns of development. The analysis allows for a nuanced discussion of the resources available and strategies each city employs for development and their relative success. GarciaFuentes et al. [5] (M3) used clustering techniques to identify the characteristics and conditions in European middle-sized cites to provide a model enabling transformation of the city ecosystem.

Smart city models appear to be a tool, not simply for measuring cities, but an aid to planning. Descriptive models and maturity models provide an ideal city state against which cities measure themselves, thus showing them where they might improve. The purposes expressed for these models included being "a tool to help cities, communities and companies to become smart" (M7), resulting in a "city action plan" (M9), for cities to "decide where they want to be" (M4) and to "build a roadmap" for the future (M6). More intricate clustering techniques are used to understand the nuances of city improvement in multiple dimensions as a starting point and guide for cities to improve.

\subsection{Composite indices}

A total of 25 composite indices were identified that attempt to put a single value on the state of a city, based on measures of a comprehensive range of city activities.

Composite indices have been proposed by academic researchers $(\mathrm{C} 5, \mathrm{C} 15, \mathrm{C} 16, \mathrm{C} 18, \mathrm{C} 23, \mathrm{C} 25)$, research groups $(\mathrm{C} 7$, $\mathrm{C} 8$ ) and institutes (C10, C13), national governments (C1, C6 and $\mathrm{C} 19)$, international bodies $(\mathrm{C} 3, \mathrm{C} 4, \mathrm{C} 12)$, and private companies (C2, C9, C11, C14, C17, C20, C21, C22, C24).

In trying to understand the different purposes of the composite indices, the stated purposes for each were compared as well as the origins of the indices, the types of cities that they targeted and whether the indices were in ongoing use or not. Four groups of indices were identified with primary purposes that were to (1) provide information, (2) to facilitate transformation, (3) commercial uses and (4) for increased knowledge of city functioning.

Seven composite indices (C1, C5, C12, C17, C18, C24) appeared to simply provide information with no explicit purpose or use for this information. They spoke in general terms of "evaluating national digital cities" (C1), creating a "comprehensive city index" that would be of interest to a broad audience (C5), ranking of cities (C12, C18) and looking at ways of combining data sources (C24).

These indices originated from private companies and individuals (C17, C22, C24), governments and international bodies (C1, C12) and academic sources (C5, C18). Two of these indices were intended for regional use, in Brazilian cities (C1) and European cities (C18). The rest had wider application. Most of these indices $(\mathrm{C} 1, \mathrm{C} 5, \mathrm{C} 17, \mathrm{C} 18, \mathrm{C} 24)$ were implemented only once or twice. One (C12) was still under development. An interesting exception was Numbeo's Quality of Life Index (C22) which supplements crowdsourced urban data with authoritative sources and provides an open information source about cities. It has been collecting and sharing data since 2009.

Table 3: Composite indices for cities

\begin{tabular}{|c|c|c|c|}
\hline NO. & NAME & PURPOSE & REF \\
\hline C1 & Brazilian Index of Digital Cities & Information & {$[38]$} \\
\hline C2 & Cities of Opportunity Index (PWC) & Commerce & {$[33]$} \\
\hline C3 & City Prosperity Index (UN-Habitat) & Transformation & {$[66]$} \\
\hline C4 & $\begin{array}{c}\text { City Prosperity Perception Index } \\
\text { (UN-Habitat) }\end{array}$ & Transformation & {$[67]$} \\
\hline C5 & CityCard Index & Information & {$[68]$} \\
\hline C6 & Ease of Living Index (India) & Transformation & {$[69]$} \\
\hline C7 & $\begin{array}{c}\text { European Smart Cities Index } \\
\text { (large cities) }\end{array}$ & Knowledge & {$[70]$} \\
\hline C8 & $\begin{array}{c}\text { European Smart Cities Index } \\
\text { (medium cities) }\end{array}$ & Knowledge & {$[70]$} \\
\hline C9 & Global Liveability Index (EIU) & Commerce & {$[10]$} \\
\hline C10 & $\begin{array}{c}\text { Global Power City Index } \\
\text { (Mori Foundation) }\end{array}$ & Knowledge & {$[34]$} \\
\hline C11 & $\begin{array}{c}\text { Global Smart City Index (Statista) } \\
\text { (U4SSC) }\end{array}$ & Commerce & {$[41]$} \\
\hline C12 & $\begin{array}{c}\text { Global Smart Sustainable Cities Index } \\
\text { Information }\end{array}$ & {$[71]$} \\
\hline
\end{tabular}




\begin{tabular}{|l|c|c|c|}
\hline NO. & NAME & PURPOSE & REF \\
\hline C13 & IESE Cities in Motion Index & Transformation & {$[72]$} \\
\hline C14 & Innovation Cities ${ }^{\text {TM Program }}$ & Commerce & {$[73]$} \\
\hline C15 & Intellectual Capital Index & Knowledge & {$[74]$} \\
\hline C16 & Intelligence Index for Portuguese Cities & Transformation & {$[75]$} \\
\hline C17 & $\begin{array}{c}\text { Italia Smart Rapporto Smart Cities Index } \\
\text { (E\&Y) }\end{array}$ & Information & {$[76]$} \\
\hline C18 & Lisbon Ranking & Information & {$[27]$} \\
\hline C19 & Liveability Index (India) & Transformation & {$[77]$} \\
\hline C20 & Mercer Quality of Living Index & Commerce & {$[78]$} \\
\hline C21 & Networked Society City Index & Knowledge & {$[79]$} \\
\hline C22 & Quality of Life Index & Information & {$[11]$} \\
\hline C23 & Shang's urbanization and innovation index & Knowledge & {$[28]$} \\
\hline C24 & Spatially adjusted liveability index (EIU) & Information & {$[80]$} \\
\hline C25 & Urban Quality Index & Transformation & {$[26]$} \\
\hline
\end{tabular}

Seven of the composite indices (C3, C4, C6, C13, C16, C19, C25) had the explicit goal of transforming cities. They were intended to monitor, prioritize investment and stimulate policy dialogue (C3), improve sustainability of cities (C4), promote healthy competition between cities (C6), connect cities and companies to develop ideas and tools to "promote change at the local level" (C13), support decision-makers (C16), develop Indian smart cities (C19) and "support cities' transformation into smart sustainable cities" (C25).

These indices originated from one international body $(\mathrm{C} 3, \mathrm{C} 4)$, one government (C6, C19), and academic research (C13, C16, C25). Four of these indices had regional foci on cities in India (C6, C19), Portugal (C16) and Europe (C13). The remaining three were intended to be applied to cities globally (C3, C4, C25). The Urban Quality Index (C25) examined "medium density neighbourhoods" of between 4000 and 10000 inhabitants. This was the only index to look at a smaller scale than a city. Four of these indices were applied only once (C6, C16, C19, C25). The two UN-Habitat indices (C3, C4) appear to be used repeatedly, but the results are not published by city, and the IESE Cities in Motion Index (C13) has been updated annually since 2014 .

Five of the composite indices (C2, C9, C11, C14, C20) have primarily commercial purposes. These indices collect data to assist client companies in compensating employees on international assignments ( $\mathrm{C} 9, \mathrm{C} 20)$, to identify cities with the "best conditions for innovation" (C14), or to gain market intelligence for their customers $(\mathrm{C} 2, \mathrm{C} 11)$.

Unsurprisingly these indices all originated from private companies. Four of them (C2, C9, C14, C20) have been updated annually for some time, but Statista's Global Smart City Index (C11) appears to have been calculated only once, in 2019.

Finally, six of the composite indices (C7, C8, C10, C15, C21, C23) have the primary goal of increased knowledge. They seek understanding of relationships between city characteristics or actions and performance. They are proposed as tools for "effective learning" about "urban innovations in specific fields of urban development" (C7, C8) or to "find relationships between "newtype urbanization" and innovation" (C23). They seek to understand the "attractive power" which draws creative individuals and business enterprises to cities (C10) or the intellectual capital of cities (C15). Or they try to "capture how cities perform in relation to sustainable operating limits and not just in relation to each other" (C21).

Most of these composite indices originated from academic research $(\mathrm{C} 7, \mathrm{C} 8, \mathrm{C} 15, \mathrm{C} 23)$ with the exception of the Global Power City Index (GPCI) (C10) from the Mori Memorial Foundation, a private research institute, and the Networked Society City Index (C21) which originated from a private company. Four of these indices were applied to cities in specific regions: Europe (C7, C8), Spain (C15) and China's Shaanxi province (C23). The other two were applied to a small selection of global cities. The Global Power City Index (C10) has been published annually since 2008 .

Composite indices claim to measure some city construct such as smartness, intelligence, economic power or liveability. Not all of the indices examined take care to define these constructs, or to validate that this is indeed what is being measured. The indices from academic sources more commonly do this, but those from national governments, international bodies and private companies appear to rely on expert opinion, rather than statistical evidence, for the validity of their claims.

This analysis suggests that composite indices for city performance can be categorized according to their intended purpose. Four explicit purposes were identified: (1) indices for information that simply sought to measure the city with no mention of how the information was to be used, (2) indices for transformation that have the explicit purpose of helping cities to transform or improve, (3) indices that are developed for commercial ends and (4) knowledge indices that were constructed to understand nuanced relationships between city systems and their functioning.

\subsection{Other smart city measures}

There were some unusual measures that did not fit into any of the above categories.

Four of the measures identified $(\mathrm{O} 1, \mathrm{O} 2, \mathrm{O} 3, \mathrm{O} 4)$ relate to competitions or awards and reflect the criteria set for the competition. In these cases, cities are expected to present applications, in a defined format, to be evaluated. Cities are told which areas or city dimensions they should provide information about, but there are no specific indicators used to evaluate these areas. Applications are assessed by a panel or committee to establish which city makes the best application overall, but there is no detailed information provided as to how the decisions are made. It would appear that the selection of winners relies on the expertise of the panel. Competition criteria originated from different sources: a regional body $(\mathrm{O} 1, \mathrm{O} 2)$, a private company (O3), and a government (O4). 
Table 4: Other measures for cities

\begin{tabular}{|c|c|c|c|}
\hline NO. & NAME & TYPE & REF \\
\hline O1 & European Green Capital Award & Competition & {$[81]$} \\
\hline O2 & European Green Leaf Award & Competition & {$[81]$} \\
\hline O3 & $\begin{array}{c}\text { Smart 21 Communities of the Year } \\
\text { Award }\end{array}$ & Competition & {$[82]$} \\
\hline O4 & Smart Cities Challenge & Competition & {$[83]$} \\
\hline O5 & City Strength Diagnostic & Evaluation process & {$[84]$} \\
\hline O6 & Smart City Assessment & Evaluation process & {$[58]$} \\
\hline O7 & Smart City Model & $\begin{array}{c}\text { Intervention } \\
\text { assessment }\end{array}$ & {$[42]$} \\
\hline O8 & $\begin{array}{c}\text { Sustainable assessment by fuzzy } \\
\text { evaluation (SAFE) for cities }\end{array}$ & $\begin{array}{c}\text { Intervention } \\
\text { assessment }\end{array}$ & {$[86]$} \\
\hline O9 & World Council on City Data & Evaluation process & {$[87]$} \\
\hline
\end{tabular}

The World Bank's City Strength Diagnostic (O5) is a five-stage evaluation process described as a "rapid diagnostic" designed to "help cities enhance their resilience to a variety of shocks and stresses". It is intended to facilitate dialogue about risks, resilience and urban system among city stakeholders. This measure is supported by a detailed "Methodological Guidebook" [84] which describes a process employing reviews, workshops, interviews and field visits to collect information and culminating in a prioritization process for deciding on actions. Similarly, IBM's Smart City Assessment (O6) is described as a "tool for assessing performance and overall capabilities against peer cities" with the goal of developing a city strategy. There is little information on the detail of this assessment with cities being invited to make contact if they are interested in the service.

Similarly, the World Council on City Data (WCCD) (O9) is a private company that collects city data using the ISO37120 indicators. They provide networking and training for cities to develop data collection capacities, and certify cities as ISO37120 compliant. Their intent appears to be commercial, with cities as their primary customers. This is not a smart city measure in itself, but a means to assist cities to improve their use of measures.

The academic papers by Lazaroiu \& Roscia [42] (O7) and Phillis et al. [86] (O8) both describe processes that use fuzzy logic to assess which interventions will most benefit cities. The first (O7) is described as a "tool for policy-makers" that "estimates the effects of their interventions, reducing subjectivity of decisions". It combines expert opinion with indicators to assess the sensitivity of city performance to changes in specific areas. The second (O8), modifies the SAFE model used to evaluate sustainability of countries, to be applied to cities. The process identifies three areas in which interventions will make the most impactful improvements.

\section{A TAXONOMY OF SMART CITY MEASURES}

Taxonomies classify items on the basis of empirically observable and measurable characteristics [88]. In this study, four distinct types of measures were identified. These include indicator standards, models, composite indices, and other measures.
Within each of these types of measures, sub-types were identified based on observed characteristics of the measures. This suggests a taxonomy of measures as shown in Table 5 . This section discusses the potential uses that cities can make of these different types of measures.

Indicator standards focus on the first level of measurement, the measurement of individual elements of a city. These are useful for researchers and policy makers as they provide a common basis for measurement and comparable measures. They can also be useful for cities as they do the work of deciding on good measures and give information about appropriate data collection. International standards reflect international goals and priorities while regional standards reflect regional goals and priorities. Cities need to be selective about which indicators they use in order to focus on their own concerns. The work of Huovila et al. [4] provides a good analysis of where indicator sets measure smartness and / or sustainability goals and also the type of indicators they offer. Cities that are at the start of their smart sustainable journey will need to use more input, process and output indicators while those further along will find outcome and impact indicators more useful.

Table 5: A taxonomy of smart city measures

\begin{tabular}{|c|c|c|}
\hline TYPE & SUB-TYPE & USES FOR CITIES \\
\hline \multirow{2}{*}{$\begin{array}{l}\text { Indicator } \\
\text { standards }\end{array}$} & Internationally defined & $\begin{array}{l}\text { Aligning with international } \\
\text { goals }\end{array}$ \\
\hline & Regionally defined & Aligning with regional goals \\
\hline \multirow{3}{*}{ Models } & Descriptive models & Simple monitoring \\
\hline & Maturity models & City development \\
\hline & Clustering models & $\begin{array}{l}\text { Deeper analysis and } \\
\text { understanding }\end{array}$ \\
\hline \multirow{4}{*}{$\begin{array}{l}\text { Composite } \\
\text { indices }\end{array}$} & Information goals & Simple city monitoring \\
\hline & Transformation goals & City development \\
\hline & Commercial goals & Benchmarking for large cities \\
\hline & Knowledge goals & $\begin{array}{l}\text { Deeper analysis and } \\
\text { understanding }\end{array}$ \\
\hline \multirow{3}{*}{$\begin{array}{c}\text { Other } \\
\text { measures }\end{array}$} & Competition criteria & Competitions \\
\hline & Evaluation process & City development \\
\hline & Intervention evaluation & Prioritising interventions \\
\hline
\end{tabular}

Models help cities to understand and map the different dimensions that need to function effectively. Descriptive models provide a language for understanding these dimensions and, sometimes, ideas for how each dimension can be measured. Descriptive models are useful tools for basic monitoring of city functions and can be a good starting point for cities.

Maturity models represent particular understandings about how an entity evolves to a more mature state $[89,90]$. A maturity model can be used to diagnose the current state of the city, as a guide to potential desired states or to facilitate internal or external benchmarking [65]. Maturity models are easy for cities to 
understand and, if they are well-defined, to apply. A good maturity model will provide the information and definitions needed to understand the model, verifiable criteria and an appropriate assessment methodology, improvement measures and a way to prioritise between them [65].

Clustering models can be useful for researchers and policy makers to understand how the characteristics of particular cities impact on their performance. These have less application at the level of city management. Cities are unlikely to have the capacity to use such tools themselves, but will be interested in the results of locally relevant studies.

Composite indicators can be grouped in terms of their intended purpose. Some of these are simple measuring tools that seek to collect and convey information about cities. Such tools can be applied as a first step towards monitoring city functioning. The second set of tools have an explicit transformation intent, seeking to assist cities to improve. Such tools are more likely to be of use in identifying city challenges and areas of improvement and they may suggest ways in which cities can develop.

Indices developed for commercial ends are important for those cities that are included. These larger cities that are capitals, or important business centers, may have no choice in whether or not they participate such rankings, but will need to pay attention to the effects of publicity surrounding the results. For cities that rank highly, these indices provide useful marketing opportunities, but for those less well ranked there is a risk that the indices distort city priorities in favour of the dimensions and measures of the rankings. For cities not included in such rankings, the indices may be useful for benchmarking themselves against other cities.

Composite indices that are developed for academic purposes are similar to clustering models in that they help researchers and policy makers to understand the measurement of city performance in more depth, but they have less application at the level of city management. Cities are unlikely to have the capacity to use such tools themselves, but will be interested in the results of locally relevant studies.

Competition criteria will be of interest only to cities eligible to participate in such competitions. These are likely to focus cities on regional goals and priorities as defined by the originators of the competition. This may be appropriate for the city, depending on who that is. For governments or regional bodies setting up such criteria there is a responsibility to ensure that the criteria serve the best interest of the region.

Measures that define processes for city evaluation could be particularly useful for cities in that they address the implementation of city measurement, which can be challenging. Instead of focusing on what is to be measured, these initiatives help cites with a process to arrive at measures. These will be helpful for cities that are seeking to improve and want to understand their current state, identify improvement strategies and develop internal capacity.

Finally, the measures that make use of advanced techniques to understand the relative impact of different interventions on city performance, will be of great interest to researchers and to policy makers seeking to understand which interventions should be supported. They will also be of interest to city management, provided that the studies are locally relevant and interpreted appropriately for cities.

\section{CONCLUSIONS}

Many different smart city measures have been proposed and many of these have been implemented. It is time to begin to understand the nature of these measures and to explore their appropriateness for different applications. This research has examined the characteristics of different smart city measures and used these characteristics to propose a taxonomy of such measures as a starting point to this work. This taxonomy provides a way to understand the different city measures that are currently in use, to distinguish between them and their potential uses for cities.

Fifty-three different tools for measuring smart, sustainable cities were identified, using a broad and inclusive interpretation of what constitutes such cities. This taxonomy identified four types of city measures and twelve sub-types. The sub-types were characterised differently for each type considering their origins, nature and goals. This is not ideal, in that the sub-types do not follow a single overarching criterion. It is hoped that further research will uncover a more satisfying basis for classification.

This study relied on desktop research using information available in publications or on web sites to understand the measures, their goals and purposes and their characteristics. The information was not uniformly detailed for all the measures. Further research may reveal mis-classifications in individual measures and this classification may need to be refined over time.

In particular, classifying the composite indices was not easy, given the range of characteristics that could have been considered. Future research needs to examine the methods used to arrive at the composite measure, the validity of the indices, and the different data sources in use. For example, few of these indices use real-time city data in keeping with the smart vision of big data analytics. Differences in rigour and data sources are likely, in future, to distinguish the usefulness of the indices and their appropriate application.

In addition, there are several measures that focus on one or other dimension of a smart city. Such measures may be able to engage with specific smart city dimensions in more depth and with the nuanced understanding that experts in the domain bring. The relationships between such dimension-specific measures and overall city measures need further exploration.

Several of the measures constructed and validated in the academic literature use interesting advanced techniques $[5,6,7,42,86]$ and reveal nuanced understandings of the relationships between city characteristics and performance. This information would be of value to cities but these studies need to be widely replicated in different contexts and with different data sets to provide applicable results. Presenting the results of this literature in a digestible format for policy makers and cities will do much to build our understanding of the success and development of different kinds of cities. 


\section{ACKNOWLEDGEMENT}

This paper is a result of the project "SmartEGOV: Harnessing EGOV for Smart Governance (Foundations, methods, Tools) / NORTE-01-0145-FEDER-000037”, supported by Norte Portugal Regional Operational Programme (NORTE 2020), under the PORTUGAL 2020 Partnership Agreement, through the European Regional Development Fund (EFDR).

\section{REFERENCES}

[1] Komninos, N. 2002. Intelligent Cities: Innovation, Knowledge Systems and Digital Spaces. London: Spon Press.

[2] Capra, C. F. 2016. The Smart City and its Citizens. International fournal of EPlanning Research, 5(1), 20-38. https://doi.org/10.4018/ijepr.2016010102

[3] Tan, F. T. C., Zhang, N., Zhu, Z., \& Leong, C. 2019. Toward Smart City Services in Beijing. In Proceedings of the 12th International Conference on Theory and Practice of Electronic Governance (ICEGOV2019), April 3-5, 2019 (pp. 513-515). Melbourne. https://doi.org/10.1145/3326365.3326445

[4] Huovila, A., Bosch, P., Airaksinen, M. 2019. Comparative analysis of standardized indicators for Smart sustainable cities: What indicators and standards to use and when? Cities, 89(January), 141-153. https://doi.org/10.1016/j.cities.2019.01.029

[5] M. García-Fuentes, A. Quijano, C. De Torre, R. García, P. Compere, C Degard, et al. 2017. European cities characterization as basis towards the replication of a smart and sustainable urban regeneration model. Energy Procedia, 111 (September 2016), pp. 836-845 https://doi.org/10.1016/j.egypro.2017.03.246

[6] Li, X., Fong, P. S. W., Dai, S., \& Li, Y. 2019. Towards sustainable smart cities: An empirical comparative assessment and development pattern optimization in China. fournal of Cleaner Production, 215, 730-743. https://doi.org/10.1016/j.jclepro.2019.01.046

[7] P. Lombardi, S. Giordano, H. Farouh, W. Yousef, 2012. Modelling the smart cityperformance. Innovation 25 (2) (2012) 137-149. https://doi.org/10.1080/13511610.2012.660325

[8] Nevado Peña, D., Alfaro Navarro, J. L., \& López Ruiz, V. R. 2017. Castilla-La Mancha Cities' Competitiveness in Intellectual Capital as Compared to Other Spanish Cities. Drustvena Istrazivanja, 26(4). https://doi.org/10.5559/di.26.4.04

[9] Rodrigues, M., Franco, M. 2019. Composite index to measure cities' creative performance: An empirical study in the Portuguese context. Sustainability (Switzerland), 11(3). https://doi.org/10.3390/su11030774

[10] The Economist Intelligence Unit web site. Retrieved from http://www.eiu.com

[11] Numbeo web site. Retrieved from https://www.numbeo.com

[12] 2thinknow web site. Retrieved from https://2thinknow.com/

[13] Hollands, R.G. 2008. Will the real smart city please stand up? Intelligent, progressive or entrepreneurial? City 12, 303-320.

[14] Giffinger, R., Fertner, C., Kramar, H., Kalasek, R., Pichler-Milanovic, N., Meijers, E. 2007. Smart cities: Ranking of European medium-sized cities. Vienna, Austria: Centre of Regional Science (SRF), Vienna University of Technology (2007).

[15] Lombardi, Patrizia, 2011. New Challenges in the Evaluation of Smart Cities. Network Industries Quarterly, 13.

[16] Munier, Nolberto. 2014. Handbook on Urban Sustainability. Springer, 2007. Retrieved Feb 2019 from http://www.springer.com/environment/environmental\%2Bmanagement/boo $\mathrm{k} / 978-1-4020-5350-4$

[17] Zhao, Jingzhu. 2011. Towards Sustainable Cities in China. Springer Briefs in Environmental Science, Springer, 2011. Retrieved Feb 2019 from http://link.springer.com/book/10.1007\%2F978-1-4419-8243-8

[18] ITU-T. 2014. Smart sustainable cities: Analysis of definitions. ITU-T Focus group on smart Sustainable Cities. Focus Group Technical Report, (10/2014). Retrieved Sept 2019 from https://www.itu.int/en/ITUT/focusgroups/ssc/Pages/default.aspx

[19] Praharaj, S., Han, J.H., Hawken, S. 2017. Urban innovation through policy integration. City Culture and Society, 12, 35-43.

[20] Yigitcanlar, T., \& Kamruzzaman, M. 2018. Does smart city policy lead to sustainability of cities? Land Use Policy, 73(January), 49-58. https://doi.org/10.1016/j.landusepol.2018.01.034
[21] Esteves, E., Lopes, N.V., Janowski, T. 2016. Smart Sustainable Cities: Reconnaissance Study. United Nations University Operating Unit on PolicyDriven Electronic Governance (UNU-EGOV).

[22] Castelnovo, W., Misuraca, G., \& Savoldelli, A. 2016. Smart cities governance: The need for a holistic approach to assessing urban participatory policy making. Social Science Computer Review, 34(6). http://dx.doi.org/10.1177/0894439315611103 (0894439315611103)

[23] Sustainable development goal 11. Retrieved Sept 2019 from https://www.un.org/sustainabledevelopment/cities/

[24] Ericsson. 2016. Networked Society City Index (2016). Retrieved Sept 2019 from www.ericsson.com/assets/local/networked-society/reports/cityindex/2016-networked-society-city-index.pdf

[25] Berrone, Ricart, Carraso, \& Ricart. 2016. IESE cities in motion index. Retrieved Sept 2019 from https://doi.org/10.15581/018.ST-471

[26] Garau, C., Balletto, G., Mundula, L. 2017. A critical reflection on smart governance in Italy: definition and challenges for a sustainable urban regeneration. In: Bisello, E.P., Vettorato, A.D., Stephens, R. (eds.), Smart and Sustainable Planning for Cities and Regions, SSPCR 2015, Green Energy and Technology, p.435.

[27] Akande, A., Cabral, P., Gomes, P., Casteleyn, S. 2019. The Lisbon ranking for smart sustainable cities in Europe. Sustainable Cities and Society, 44, 475487. https://doi.org/10.1016/j.scs.2018.10.009

[28] Shang, J., Wang, Z., Li, L., Chen, Y., Li, P. 2018. A study on the correlation between technology innovation and the new-type urbanization in Shaanxi province. Technological Forecasting and Social Change, 135(April), 266-273. https://doi.org/10.1016/j.techfore.2018.04.029

[29] Bolivar, M. P. R., \& Meijer, A. J. 2016. Smart governance: Using a literature review and empirical analysis to build a research model. Social Science Computer Review, 34(6), 1-20. http://dx.doi.org/10.1177/0894439315611088

[30] Kourtit, K., Nijkamp, P., \& Arribas, D. 2012. Smart cities in perspective - A comparative European study by means of self-organizing maps. Innovation: The European fournal of Social Science Research, 25(2), 229-246. http://dx.doi.org/10.1080/13511610.2012.660330

[31] Ruhlandt, R. W. S. 2018. The governance of smart cities: A systematic literature review. Cities, 81(June), 1-23. https://doi.org/10.1016/j.cities.2018.02.014

[32] Chatfield, A. T., \& Reddick, C. G. 2016. Smart city implementation through shared vision of social innovation for environmental sustainability: A case study of Kitakyushu, Japan. Social Science Computer Review, 34(6), 757-773. http://dx.doi.org/10.1177/0894439315611085

[33] PWC Cities of Opportunity. Retrieved Sept 2019 from https://www.pwc.com/us/en/library/cities-of-opportunity.html

[34] Ichikawa, H., Yamato, N., \& Dustan, P. 2017. Competitiveness of Global Cities from the Perspective of the Global Power City Index. Procedia Engineering, 198(September 2016), 736-742. https://doi.org/10.1016/j.proeng.2017.07.125

[35] Dall'O, G., Bruni, E., Panza, A., Sarto, L., Khayatian, F. 2017. Evaluation of cities' smartness by means of indicators for small and medium cities and communities: A methodology for Northern Italy. Sustainable Cities and Society, 34(July), 193-202. https://doi.org/10.1016/j.scs.2017.06.021

[36] Hara, M., Nagao, T., Hannoe, S., \& Nakamura, J. 2016. New key performance indicators for a smart sustainable city. Sustainability (Switzerland), 8(3). https://doi.org/10.3390/su8030206

[37] Caragliu, A., Del Bo, C., Nijkamp, P. 2011. Smart cities in Europe. fournal of Urban Technology 18, 65-82, (2011). http://dx.doi.org/10.1080/10630732.2011.601117

[38] Duarte, F., Figueiredo, F. de C., Leite, L., \& Rezende, D. A. 2014. A Conceptual Framework for Assessing Digital Cities and the Brazilian Index of Digital Cities: Analysis of Curitiba, the First-Ranked City. Journal of Urban Technology, 21(3), 37-48. https://doi.org/10.1080/10630732.2014.940709

[39] Hoornweg, D. A., Campillo, G., Linders, D., Saldivar-Sali, A. N., \& Sugar, L. 2013. Mainstreaming Urban Metabolism: Advances and challenges in city participation. In Proceedings of the Sixth Urban Research and Knowledge Symposium.

[40] Marsal-Llacuna, M. L., Colomer-Llinàs, J., Meléndez-Frigola, J. 2015. Lessons in urban monitoring taken from sustainable and livable cities to better address the Smart Cities initiative. Technological Forecasting and Social Change, 90(PB), 611-622. https://doi.org/10.1016/j.techfore.2014.01.012

[41] Statista web site. Accessed Sept 2019 at https://www.statista.com/statistics/826003/global-smart-city-index/

[42] Lazaroiu, G. C., \& Roscia, M. 2012. Definition methodology for the smart cities model. Energy, 47(1), 326-332. https://doi.org/10.1016/j.energy.2012.09.028 
[43] Ojo, A., Curry, E., \& Janowski, T. 2014. Designing next generation Smart City initiatives - Harnessing findings and lessons from a study of ten Smart City programs. In Proceedings of the European Conference on Information Systems (ECIS), 2014, pp.0-14. Tel Aviv, Israel.

[44] Nesti, G. 2018. Defining and assessing the transformational nature of smart city governance: Insights from four European cases. International Review of Administrative Sciences. https://doi.org/10.1177/0020852318757063

[45] Backhouse, J. 2019. A Review of Measures to Evaluate Smart Sustainable Cities. In Proceedings of the EAI International Conference on Smart Governance for Sustainable Smart Cities (SmartGov 2019), Braga, Dec 4-6, 2019, Braga, Portugal.

[46] City Keys Deliverable 4.1 Smart City KPIs and related methodology. Retrieved Sept 2019 from http://nws.eurocities.eu/MediaShell/media/D1.4CITYkeys D14 Smart City KPIs Final 20160201.pdf

[47] European Telecommunications Standards Institute (ETSI). 2017. ETSI TS 103 463 V1.1.1 (2017-07), Technical Specification, Key Performance Indicators for Sustainable Digital Multiservice Cities. Retrieved Sept 2019 from https://www.etsi.org/deliver/etsi ts/103400 103499/103463/01.01.01 60/ts 1 03463v010101p.pdf

[48] International Organization for Standardization (ISO). 2018. Sustainable Development of Communities - Indicators for City Services and Quality of Life. 37120:2018(E).

[49] International Organization for Standardization (ISO). 2019. Sustainable cities and communities - Indicators for smart cities ISO 37122:2019(E).

[50] International Organization for Standardization (ISO). N.D. ISO 37123 Sustainable cities and communities - Indicators for resilient cities Retrieved Sept 2019 from https://www.iso.org/standard/70428.html

[51] International Telecommunication Union (ITU-T). 2016. ITU-T Y.4901/L.1601 Key Performance Indicators related to the use of information and communication technology in smart sustainable cities. Retrieved 26/09/2019 from https://www.itu.int/rec/T-REC-L.1601-201606-I/en

[52] International Telecommunication Union (ITU-T). 2016. ITU-T Y.4901/L.1601 Key Performance Indicators related to the sustainabiliy impacts of information and communication technology in smart sustainable cities. Retrieved 26/09/2019 from https://www.itu.int/rec/T-REC-L.1602-201606-I

[53] International Telecommunication Union (ITU-T). 2016. ITU-T Y.4903/L.1603 Key Performance Indicators for smart sustainable cities to assess the achievement of sustainable development goals. https://www.itu.int/rec/TREC-Y.4903-201610-I/en

[54] ITU-T (2014). Overview of Key Performance Indicators in Smart Sustainable Cities, (2014). ITU-T Focus group on smart Sustainable Cities. Focus Group Technical Specifications. Retrieved 26/09/19 from https:/www.itu.int/en/ITU-T/focusgroups/ssc/Pages/default.aspx

[55] Inter-Agency and Expert Group on Sustainable Development Goal Indicators. 2016. Final list of proposed SDG indicators. Retrieved 26/09/19 from https://sustainabledevelopment.un.org/content/documents/11803OfficialList-of-Proposed-SDG-Indicators.pdf

[56] Scottish Government Smart Cities Maturity Model and Self-Assessment tool. Dec 31, 2013. Retrieved October 2019. https://shift.tools/resources/1335

[57] EU-China Smart and Green City Cooperation, March 2014. Comparative Study of Smart Cities in Europe and China. White Paper prepared for Ministry of Industry and Information Technology (MIIT). Retrieved October 2019 from https://www.academia.edu/9336293/EUChina Smart and Green City Cooperation Comparative Study of Smart Cities in Europe and China -White Paper prepared for Acknowledgements

[58] IBM. How Smart is Your City? Helping Cities Measure Progress. IBM Global Business Services. Retrieved Sept 2019 from https://doi.org/10.1126/science.1217637

[59] Cohen B. 2014. The smartest cities in the world, 2015 methodology. Retrieved Oct 2019 from http://www.fastcoexist.com/3038818/the-smartestcities-in-the-world-2015-methodology

[60] IBM Smarter Cities Challenge Pittsburgh report, N.D. Retrieved Oct 2019 from http://www.utc.ices.cmu.edu/utc/IBM Smarter Cities Report 2013.pdf

[61] UN Habitat City Prosperity Initiative. Retrieved Sept 2019 from https://unhabitat.org/urban-initiatives/initiatives-programmes/cityprosperity-initiative/

[62] Nolan, R. L. 1973. Managing the computer resource: A stage hypothesis. Communications of the ACM. 16 (7), 399-405. https://doi.org/10.1145/362280.362284
[63] Humphrey, W. S. 1988. Characterizing the software process: a maturity framework. IEEE Software, 5(2), 73-79. https://doi.org/10.1109/52.2014. ISSN 0740-7459

[64] Klimko, G. 2001. Knowledge Management and Maturity Models: Building Common Understanding. Proceedings of the Second European Conference on Knowledge Management, Bled School of Management, Bled, Slovenia 8-9 November, pp $269-278$.

[65] Pöppelbuß, Jens \& Röglinger, Maximilian, 2011. What Makes A Useful Maturity Model? A Framework Of General Design Principles For Maturity Models And Its Demonstration In Business Process Management. ECIS 2011 Proceedings. http://aisel.aisnet.org/ecis2011/28

[66] ESCAP and UN-HABITAT. March 2018. City Prosperity Initiative Conceptualization and Application. Retrieved Oct 2019 from https://www.unescap.org/sites/default/files/4.City Prosperity Innitiative U N-Habitat_Wshop_26-29Mar2018.pdf

[67] UN-Habitat. N.D. City Prosperity Initiative - Perception Index. Retrieved Oct 2019 from http://www.perceptionindex.org/

[68] Grant and Chuang, 2012. An aggregating approach to ranking cities for knowledge-based development. International fournal of Knowledge-Based Development, 3(1), 17-34.

[69] ZeeNews. Sept 2018, Ease of Living: AP, Odisha and Madhya Pradesh best states to live. Retrieved Oct 2019 from https://zeenews.india.com/india/apodisha-and-mp-top-ease-of-living-index-2143402.html

[70] European Smart Cities web site. Retrieved Oct 2019 from http://www.smartcities.eu/

[71] Private communication, September 2019.

[72] IESE Cities in Motion Index 2019. Retrieved Oct 2019 from https://media.iese.edu/research/pdfs/ST-0509-E.pdf

[73] 2thinknow web site. Retrieved Oct 2019 at https://2thinknow.com/

[74] Nevado Peña, D., Alfaro Navarro, J. L., \& López Ruiz, V. R. 2017. Castilla-La Mancha Cities' Competitiveness in Intellectual Capital as Compared to Other Spanish Cities. Drustvena Istrazivanja, 26(4). https://doi.org/10.5559/di.26.4.04

[75] Rodrigues, M., Franco, M.: Composite index to measure cities' creative performance: An empirical study in the Portuguese context. Sustainability (Switzerland), 11(3). https://doi.org/10.3390/su11030774

[76] Ernst, Young. 2016. Rapporto Smart city index. Retrieved Sept 2019 from www.ey.com/...smart...index-2016/.../2016-EY-smart-city-index

[77] Smart Cities Council, India web site. Retrieved Oct 2019 from https://india.smartcitiescouncil.com/article/india-launches-liveability-indexrank-116-indian-cities

[78] Mercer. 2014. Quality of Living Worldwide Rankings-Mercer Survey. New York. 2014. Retrieved Oct 2019 from http://www.uk.mercer.com/newsroom/2014-quality-of-living-survey.html

[79] Networked Society City Index. 2016. Cities play key role in sustainable development. Retrieved Oct 2019 from www.ericsson.com/assets/local/networked-society/reports/city-index/2016networked-society-city-index.pdf.

[80] Time. 2012. And the Best City in the World is: Retrieved Oct 2019 from http://newsfeed.time.com/2012/07/09/and-the-best-city-in-the-world-is

[81] European Green Capital and European Green Leaf Awards web site. Retrieved Oct 2019 from https://www.egcaeglaportal.eu/

[82] ICF Intelligent Community Forum web site. Retrieved Oct 2019 from https://www.intelligentcommunity.org/

[83] Government of India Smart Cities Mission web site. Retrieved Oct 2019 from http://www.smartcities.gov.in/content/

[84] Lynch, Catherine. 2018. CityStrength diagnostic. Methodological guidebook (English). Washington, D.C. World Bank Group. http://documents.worldbank.org/curated/en/996471525721935888/CityStren gth-diagnostic-methodological-guidebook

[85] IBM How smart is your city? Retrieved Oct 2019 from https://www.ibm.com/services/us/gbs/bus/html/ibv-smarter-citiesassessment.html

[86] Phillis, Y.A., Kouikoglou, V.S., \& Verdugo, C. 2017. Urban sustainability assessment and ranking of cities. Computers, Environment and Urban Systems, 64, 254-265. https://doi.org/10.1016/j.compenvurbsys.2017.03.002

[87] World Council on City Data web site. Retrieved Oct 2019 from https://www.dataforcities.org

[88] Smith, K.B., 2002. Typologies, Taxonomies and the Benefits of Policy Classification. Policy Studies fournal, 30(3), 379-395.

[89] Gottschalk, P. 2009. Maturity levels for interoperability in digital government. Government Information Quarterly, 26(1), 75-81. 
[90] Kazanjian, R. K. and Drazin, R. 1989. An empirical test of a stage of growth progression model. Management Science, 35(12), 1489-1503. 